\title{
Trampling on rocky shores by an introduced capybara population in Anchieta Island State Park, Brazil
}

\author{
Maria Laura Ternes * \\ Programa de Pós-Graduação em Ecologia Aquática e Pesca \\ Universidade Federal do Pará, Campus do Guamá \\ Rua Augusto Corrêa, 1, CEP 66.075-110, Belém - PA, Brasil \\ * Autor para correspondência \\ marialaura.ft@gmail.com
}

Submetido em $05 / 10 / 2018$

Aceito para publicação em 05/04/2019

\section{Resumo}

Pisoteio em costões rochosos por uma população de capivaras introduzida no Parque Estadual da ilha Anchieta, Brasil. Este estudo descreve um caso incomum de pisoteio nos costões rochosos entremarés pela maior espécie de mamífero roedor, a capivara, Hydrochoerus hydrochaeris (Linnaeus, 1766). Grupos de capivaras foram observados nadando, mergulhando e descansando ao longo de costões rochosos do Parque Estadual da Ilha Anchieta, Ubatuba, São Paulo. São discutidos os possíveis efeitos do pisoteio diário em costões rochosos por uma grande e incontrolada população de capivaras, bem como as intervenções de manejo e pesquisa necessárias.

Palavras-chave: Área protegida; Espécie introduzida; Conservação costeira; Gestão ambiental; Zona entremarés

\section{Abstract}

This study describes an unusual case of trampling on intertidal rocky shores by the largest rodent, the capybara, Hydrochoerus hydrochaeris (Linnaeus, 1766). Groups of capybaras were sighted swimming, diving and resting along the rocky shores of Anchieta Island State Park, Brazil. The possible effects of daily trampling on rocky shores by a large and uncontrolled capybara population are discussed, and management and research interventions are proposed.

Key words: Coastal conservation; Environmental management; Intertidal zone; Introduced species; Protected area

Human trampling on intertidal reefs can have a negative impact on biota, even at low intensities (FERREIRA; ROSSO, 2009). On rocky shores, the effects of trampling are the reduction of the population, cover and biomass of benthic organisms such as non-crustose algae (SCHIEL; TAYLOR, 1999), bivalves (FERREIRA; ROSSO, 2009), polychaetes (BROWN; TAYLOR, 1999), and barnacles (BROSNAN; CRUMRINE, 1994), thereby changing the population dynamics and diversity of the community (HUFF, 2011; POUR et al., 2013; MICHELI et al., 2016). In this context, the effects of trampling have been a matter of 
concern among managers and researchers, mainly at touristic destinations. A simple management measure adopted to mitigate trampling impacts is zoning areas, reducing or eliminating the trampling.

This communication describes an unusual case of daily trampling on rocky shores of a Brazilian coastal island, caused by an introduced and uncontrolled rodent species, the capybara, Hydrochoerus hydrochoeris (Linnaeus, 1766). Furthermore, recommendations highlight management interventions and additional surveys to verify the possible impacts of trampling.

Anchieta Island $\left(23^{\circ} 27^{\prime} \mathrm{S}\right.$; $\left.45^{\circ} 02^{\prime} \mathrm{W}\right)$ comprises an $8.26 \mathrm{~km}^{2}$ land-bridge island in the Atlantic Ocean, southeastern Brazil. The island has had a secular history of human occupation and was the site of a prison from 1908 to 1955 . In 1977, the island became a State Park under conservation regulations and since then has turned into one of the main touristic attractions of the southeastern Brazilian coast. In 1983, the São Paulo zoo introduced on Anchieta Island 100 mammals belonging to 15 species, including seven individuals of capybara. The species is the largest rodent in the world, weighing more than $60 \mathrm{~kg}$ (MOREIRA et al., 2012). The population of capybaras increased 38 times, with as many as 272 individuals in 2006, accounting for the highest density of herbivorous mammals in the Atlantic forest (BOVENDORP; GALETTI, 2007). Since then, there has been an urgent need to eradicate or, at least, control the population, because these herbivores are directly affecting the recruitment of plants and consequently the restoration of the vegetation (BOVENDORP; GALETTI, 2007; ALVAREZ et al., 2008; FADINI et al., 2009). However, environmental legislation, managers, and public opinion continue to be mistaken regarding introduced species, which hampers the management of charismatic animals such as mammals (BOVENDORP; GALETTI, 2007). Meanwhile, the forest system of Anchieta Island State Park is severely altered by the introduced species.

During January 2017, a group of capybaras was sighted in the coastal water along the rocky shores of two sites in the Anchieta Island, swimming at Palmas Beach (Figure 1a) and diving at Engenho Beach (Figure 1b). Groups of capybaras swim daily along the rocky shore in the morning. Rocky shores of Anchieta Island are conserved environments since the park is a notake Marine Protected Area established over the last 30 years. These sites are visited by recreational snorkelers, mainly during the austral summer. On three occasions, groups of 5-7 capybaras were observed on the intertidal rocky shore of Engenho Beach (Figure 1c). Once, the group was scared by human presence and came out of the water trampling on the rocks. On two other occasions, the group was apparently resting, lying down on the rocks. There are more than 270 capybaras on Anchieta Island and possibly more than one group diving along the rocky shore.

Besides the negative effects on the terrestrial realm, capybaras may have an impact on the marine environment, by trampling daily on intertidal rocky shores. A group of capybaras was swimming daily at the same site and using the rocky shores as a resting place, trampling in a region where benthic organisms occur, such as algae (PEREIRA, 2007), crustaceans (MANTELATTO; GARCIA, 2002; BIAGI; MELO, 2004), mollusks (FERREIRA; ROSSO, 2009) and other invertebrates. The mechanical effect of trampling could reduce the abundance of these organisms by dislodgement or damage, causing their death (BALLY; GRIFFITHS, 1989; HUFF, 2011; POUR et al., 2013). In agreement with other studies (e.g., BOVENDORP; GALETTI, 2007; FADINI et al., 2009), the present communication reinforces the need for population control (or eradication) of capybaras on Anchieta Island and further studies to characterize this population of capybaras and their habits to assess, mitigate and prevent their potential trampling impact on marine environments. Trampling can exert considerable effects on rocky shores, so managers need to take this into account and implement strategies to mitigate this potential impact. Additional studies, such as monitoring biomass, richness and diversity of benthic organisms at trampled sites and control sites, need to be conducted to verify if capybaras are having negative effects on benthic communities. The last version of the Anchieta Island State Park management plan dates from 1989 and has no standards about the management of introduced species (GUILLAUMON et al., 1989). It is time for 
FIGURE 1: (a) Capybaras swimming at Palmas Beach; (b) diving at Engenho Beach; (c) trampling on the intertidal rocky shore of Engenho Beach.
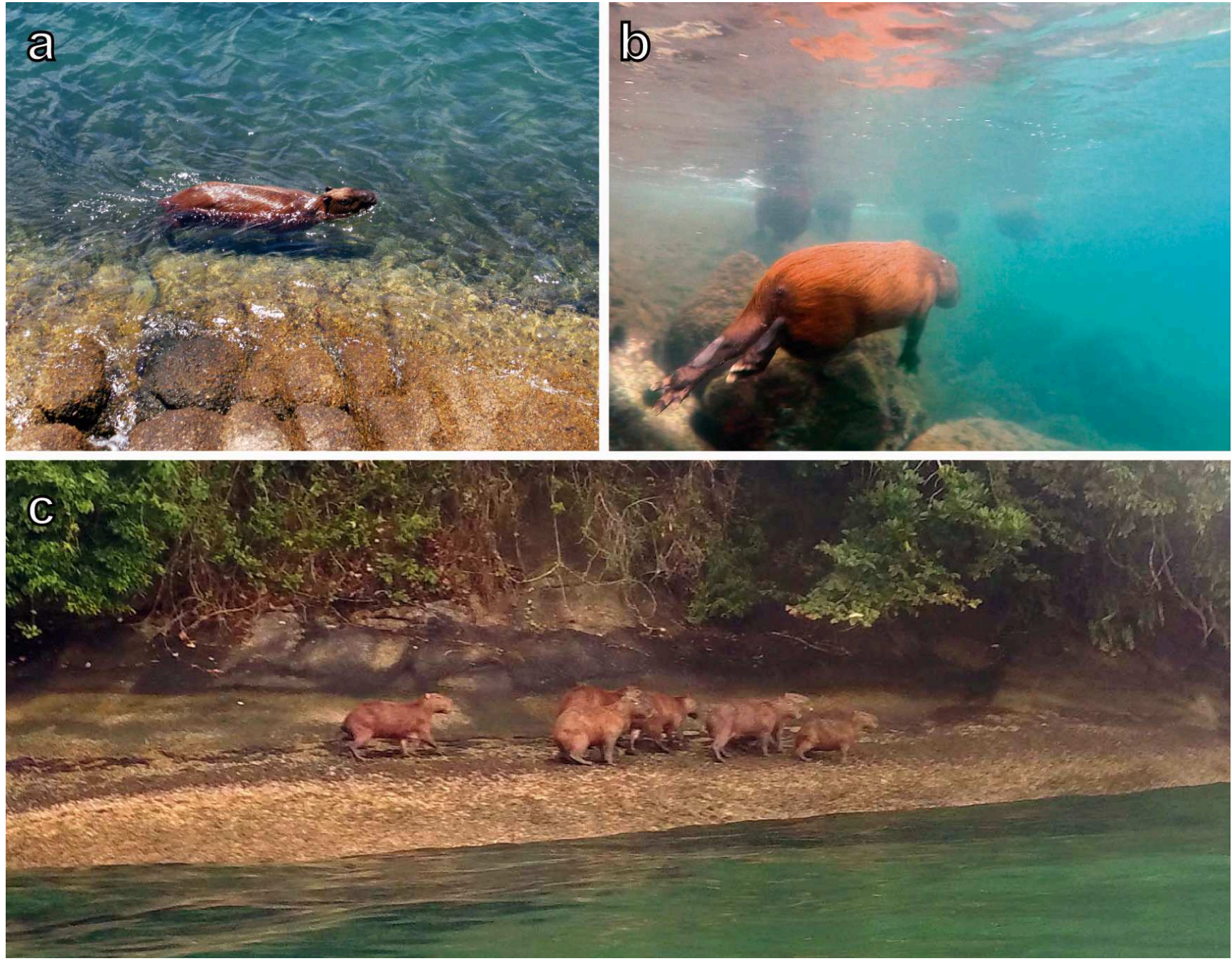

managers to fully implement measures for the effective conservation of this protected area.

\section{Acknowledgements}

I thank the Anchieta Island State Park administration and staff for their support. VJ Giglio provided comments on the manuscript.

\section{References}

ALVAREZ A. D.; BOVENDORP, R. S.; FLEURY, M.; GALETTI, M. Um paraíso de "exóticos." Ciência Hoje, Rio de Janeiro, v. 41, n. 246, p. $69-71,2008$.
BALLY, R.; GRIFFITHS, C. Effects of human trampling on an exposed rocky shore. International Journal of Environmental Studies, Deux-Sevres, v. 34, n. 1-2, p. 115-125, 1989.

BIAGI, R.; MELO, G. A. Majoid crabs community (Crustacea: Decapoda) from infralittoral rocky/sandy bottom of Anchieta Island, Ubatuba. Brazilian Archives of Biology and Technology, Curitiba, v. 47, p. 273-279, 2004.

BOVENDORP, R. S.; GALETTI, M. Density and population size of mammals introduced on a land-bridge island in southeastern Brazil. Biological Invasions, Dordrecht, v. 9, p. 353-357, 2007.

BROSNAN, D. M.; CRUMRINE, L. L. Effects of human trampling on marine rocky shore communities. Journal of Experimental Marine Biology and Ecology, Amsterdam, v. 177, p. 79-97, 1994. BROWN, P. J.; TAYLOR, R. B. Effects of trampling by humans on animals inhabiting coralline algal turf in the rocky intertidal. Journal of Experimental Marine Biology and Ecology, Amsterdam, v. 235, p. 45-53, 1999. 
FADINI, R. F.; FLEURY, M.; DONATTI, C. I.; GALETTI, M. Effects of frugivore impoverishment and seed predators on the recruitment of a keystone palm. Acta Oecologica, Paris, v. 35, p. 188-196, 2009.

FERREIRA, M.; ROSSO, S. Effects of human trampling on a rocky shore fauna on the Sao Paulo coast, southeastern Brazil. Brazilian Journal of Biology, São Carlos, v. 69, p. 993-999, 2009.

GUILLAUMON, J. R.; MARCONDES, M. A. P.; NEGREIROS, O. O.; MOTA, I. S.; EMMERICH, W.; BARBOSA, A. F.; BRANCO, I. H. D. C.; CAMARA, J. J. C.; OSTINI, S.; PEREIRA, R. T. L.; SCORVO-FILHO, J. D.; SHIMOMICHI, P. Y.; MELO-NETO, J. E. S. Plano de Manejo do Parque Estadual da Ilha Anchieta. São Paulo: Instituto Florestal de São Paulo, 1989. 103 p.

HUFF, T. M. Effects of human trampling on macro and meiofauna communities associated with intertidal algal turfs and implications for management of protected areas on rocky shores (Southern California). Marine Ecology, Berlin, v. 32, p. 335-345, 2011.

MANTELATTO, F. L.; GARCIA, R. B. Hermit crab fauna from the infralittoral zone of Anchieta Island (Ubatuba, Brazil). In: ESCOBAR-BRIONES, E.; ALVAREZ, F. M. (Ed.). Approaches to the study of Crustacea. New York: Springer, 2002. p. 137-143.
MICHELI, F.; HEIMAN, K. W.; KAPPEL, C. V.; MARTONE, R. V.; SETHI, S. A.; OSIO, G. C.; FRASCHETTI, S.; SHELTON, A. O.; TANNER, J. N. Combined impacts of natural and human disturbances on rocky shore communities. Ocean \& Coastal Management, Augustinusga, v. 126, p. 42-50, 2016.

MOREIRA, J. R.; FERRAZ, K. M. P.; HERRERA, E. A.; MACDONALD, D. W. Capybara: biology, use and conservation of an exceptional neotropical species. New York: Springer-Verlag, 2012. $422 \mathrm{p}$.

PEREIRA, A. P. V. Caracterização fisionômica da comunidade marinha bentônica de substrato consolidado do infralitoral no costão oeste da enseada das Palmas, ilha Anchieta, Ubatuba São Paulo - Brasil. 2007. 335 f. Tese (Doutorado em Botânica) - Universidade de São Paulo, São Paulo. 2007.

POUR, F. A.; SHOKRI, M. R.; ABTAHI, B. Visitor impact on rocky shore communities of Qeshm Island, the Persian Gulf, Iran. Environmental Monitoring and Assessment, Dordrecht, v. 185, p. 1859-1871, 2013.

SCHIEL, D. R.; TAYLOR, D. I. Effects of trampling on a rocky intertidal algal assemblage in southern New Zealand. Journal of Experimental Marine Biology and Ecology, Amsterdam, v. 235, p. 213-235, 1999. 